JURNAL KETAHANAN NASIONAL

Vol.23, No.3, Desember 2017, Hal 359-375

DOI:http://dx.doi.org/ 10.22146/jkn.25500

ISSN:0853-9340(Print), ISSN:2527-9688(Online)

Online sejak 28 Desember 2015 di :http://jurnal.ugm.ac.id/JKN

VOLUME 23

No. 3, Desember 2017

Halaman 359-375

\title{
Hubungan Ketahanan Pangan Keluarga Dengan Status Gizi Balita (Studi Di Desa Palasari Dan Puskesmas Kecamatan Legok, Kabupaten Tangerang)
}

\author{
Afrizal Arlius \\ Denpal Divisi Infanteri 1 Kostrad \\ Email: afrizalarlius@ymail.com \\ Toto Sudargo \\ Fakultas Kedokteran Program Studi Gizi Univ. Gadjah Mada \\ Email: toto_sudargo@yahoo.co.id \\ Subejo \\ Fakultas Pertanian Univ. Gadjah Mada \\ Email: subejo1972@yahoo.com
}

\begin{abstract}
The aims of study were to examined the relationship of food resilience with the nutritional status and the variety of efforts to improved food resilience in malnutrition prevention of children under five years old in the working area of Puskesmas Legok, Legok District, Tangerang Regency.

The population in this study were parents/mother/father and children under 59 months age who suffered from hunger and malnutrition under normal conditions.

The program of social nutrient upgrading or toddlers at Legok Puskesmas was conducted daily, monthly and yearly. The daily programs were the increasing of exclusive breastfeeding (milk) without extra food and drinks for babies up to age 6 months. The monthly program was the monitoring to evaluated the development of underweight body weight, weighing the infants that was weighing weight measurement of toddler to knew growth pattern and development of toddler body and their development. The annual program was the monitoring for the nutritional status of children under five years old and nutrient intake.
\end{abstract}

Keywords: Food Resilience, Nutritional Status, Children Under Five Years Old, Legok District.

\begin{abstract}
Penelitian ini bertujuan untuk mengkaji hubungan ketahanan pangan dengan status gizi balita dan ragam upaya meningkatkan ketahanan pangan dalam penanggulangan gizi buruk balita di wilayah kerja Puskesmas Legok, Kecamatan Legok, Kabupaten Tangerang.

Populasi penelitian adalah orang tua/ibu/bapak dan balita umur di bawah 59 bulan yang menderita gizi buruk dan kurang gizi di bawah kondisi normal.

Program peningkatan gizi masyarakat atau balita di Puskesmas Legok dilaksanakan secara harian, bulanan dan tahunan. Program harian meliputi: peningkatan pemberian Air Susu Ibu (ASI) eksklusif tanpa makanan dan minuman tambahan untuk bayi sampai umur 6 bulan. Program bulanan adalah pemantauan perkembangan berat badan balit, penimbangan badan balita, yaitu pengukuran berat badan balita untuk mengetahui pola pertumbuhan dan perkembangan peningkatan berat badan balita dan perkembangannya. Program tahunan meliputi pemantauan status gizi dan asupan gizi balita.
\end{abstract}




\section{PENGANTAR}

Ketahanan pangan merupakan suatu kondisi ketersediaan pangan yang cukup bagi setiap orang pada setiap saat dan setiap individu yang mempunyai akses untuk memperolehnya, baik secara fisik maupun ekonomi. Fokus ketahanan pangan tidak hanya pada penyediaan pangan tingkat wilayah tetapi juga ketersediaan dan konsumsi pangan tingkat daerah dan rumah tangga, dan bahkan bagi individu dalam memenuhi kebutuhan gizinya. Kebijakan pemerintah dalam ketahanan pangan ini dapat dianalisis dari diterbitkannya Undang-Undang Republik Indonesia Nomor 7 Tahun 1996 tentang Pangan. Dalam undangundang tersebut dinyatakan bahwa ketahanan pangan adalah kondisi terpenuhinya pangan bagi rumah tangga yang tercermin dari ketersediaan pangan yang cukup, baik jumlah maupun mutu, aman, merata, dan terjangkau. Hal itu diperkuat dengan diterbitkannya Peraturan Presiden Republik Indonesia Nomor 83 Tahun 2006 tentang Pembentukan Dewan Ketahanan Pangan.

Perkembangan terbaru dalam sistem hukum menunjukkan bahwa Undang-Undang No. 18 Tahun 2012 mendefinisikan ketahanan pangan sebagai kondisi terpenuhinya pangan bagi negara sampai dengan perseorangan, yang tercermin dari tersedianya pangan yang cukup, baik jumlah maupun mutunya, aman, beragam, bergizi, merata, dan terjangkau serta tidak bertentangan dengan agama, keyakinan, dan budaya masyarakat, untuk dapat hidup sehat, aktif, dan produktif secara berkelanjutan. Uraian tersebut di atas menunjukkan bahwa ketahanan pangan merupakan salah satu isu penting yang harus segera diwujudkan bagi segenap pihak (Ariani dan Pitono, 2014).

Pentingnya ketahanan pangan di antaranya dikarenakan ketahanan pangan mempengaruhi status gizi masyarakat itu sendiri. Jika ketahanan pangan kurang maka status gizi otomatis menjadi kurang dan menyebabkan turunnya derajat kesehatan. Dengan demikian maka ketahanan pangan sangat erat kaitannya dengan aspek gizi dan kesehatan. Apabila ketahanan pangan yang selalu kurang dari kecukupan dalam jangka waktu tertentu dapat mengakibatkan kurang gizi walaupun tidak menderita penyakit. Akan tetapi, ketahanan pangan yang cukup, namun masyarakat terjangkit penyakit, dapat menyebabkan kurang gizi. Hasil penelitian Soblia (2009) menunjukkan bahwa tingkat ketahanan pangan rumah tangga memiliki korelasi yang positif dan signifikan dengan tingkat konsumsi energi dan protein balita.

Gizi buruk merupakan istilah teknis yang biasanya digunakan oleh kalangan masyarakat pemerhati gizi, kesehatan dan kedokteran. Gizi buruk adalah kondisi seseorang yang asupan nutrisinya di bawah rata-rata. Hal ini merupakan suatu kondisi terparah dari proses kekurangan gizi yang sifatnya menahun.

Dalam rangka memahami hubungan ketahanan pangan dengan status gizi balita perlu disampaikan beberapa konsep, sebagai berikut.

Pertama, ketahanan pangan. Ketahanan pangan ini pada dasarnya membicarakan soal ketersediaan pangan (food avaibilitas), stabilitas harga pangan (food price stability), dan keterjangkauan pangan (food accessibility). Ketersediaan pangan yang cukup berarti rata-rata jumlah dan mutu gizi pangan yang tersedia di masyarakat dan pasar mencukupi kebutuhan untuk konsumsi semua rumah tangga (Soekirman 2000).

Menurut Peraturan Pemerintah No 68 Tahun 2002 dan UU Pangan No 18 Tahun 2012 tentang Ketahanan Pangan, maka ketahanan 
pangan merupakan kondisi terpenuhinya pangan bagi rumah tangga yang tercermin dari ketersediaan pangan yang cukup, baik jumlah, maupun mutunya, aman, merata, dan konsumsi pangan yang cukup merupakan syarat mutlak terwujudnya ketahanan pangan rumah tangga. Ketidaktahanan pangan dapat digambarkan dari perubahan konsumsi pangan yang mengarah pada penurunan kuantitas dan kualitas termasuk perubahan frekuensi konsumsi makanan pokok.

Ketahanan pangan menekankan pada pengamanan kesejahteraan keluarga, salah satunya adalah kecukupan pangan sebagai alat mencapai kesejahteraan. Stabilitas pangan berarti menjaga agar tingkat konsumsi pangan rata-rata rumah tangga tidak turun sampai di bawah kebutuhan yang seharusnya. Ketahanan pangan keluarga erat hubungannya dengan ketersediaan pangan yang merupakan salah satu faktor atau penyebab tidak langsung yang berpengaruh pada status gizi anak (Soekirman, 2000).

Kedua, pengukuran gizi buruk pada balita. Untuk mengetahui status gizi yang terjadi di masyarakat dapat dilakukan dengan menggunakan beberapa pengukuran. (1). Pengukuran klinis. Metode ini penting untuk mengetahui status gizi balita tersebut apakah berstatus gizi buruk atau tidak. Metode ini mendasarkan perubahan-perubahan fisik anggota tubuh atau yang terjadi pada balita dan dihubungkan dengan kecukupan gizi atau status gizinya. Hal ini dapat dilihat pada jaringan epitel seperti kulit, rambut atau mata. Misalnya pada balita penderita marasmus maka kulit menjadi keriput. Sedangkan pada balita penderita kwashiorkor maka muncul bercak-bercak putih atau merah muda (crazy pavement dermatosis) pada permukaan kulit. (2). Pengukuran antropometrik. Metode ini dilakukan beberapa macam pengukuran antara lain pengukuran berat badan (BB), tinggi badan (TB), dan lingkar lengan atas. Pengukuran tersebut di atas paling sering dilakukan dalam survei gizi terhadap balita berdasarkan kelompok umurnya. Dalam ilmu gizi, maka status gizi tidak hanya diketahui dengan mengukur berat badan (BB) atau tinggi badan (TB) berdasarkan umur secara sendiri-sendiri, tetapi juga dalam bentuk indikator yang dapat merupakan kombinasi dari ketiganya. Indikator yang dapat mempengaruhi status gizi antara lain penyebab langsung yaitu makanan dan penyakit infeksi yang mungkin diderita. Timbulnya gizi kurang bukan saja karena makanan yang kurang tetapi juga karena penyakit dan penyebab tidak langsung yaitu ketahanan pangan di keluarga, pola pengasuhan anak, pelayanan kesehatan dan kesehatan lingkungan merupakan faktor yang saling berhubungan. Sedangkan penyebab mendasar atau akar masalah gizi di atas adalah terjadinya krisis ekonomi, politik, dan sosial termasuk bencana alam, yang mempengaruhi ketidakseimbangan antara asupan makanan dan adanya penyakit infeksi, yang pada akhirnya mempengaruhi status gizi balita (Soekirman, 2000).

Indikator berat- badan/usia $(\mathrm{BB} / \mathrm{U})$ menunjukkan secara sensitif status gizi saat ini (saat diukur) karena mudah berubah, namun tidak spesifik karena berat badan selain dipengaruhi oleh umur juga dipengaruhi oleh tinggi badan. Indikator ini dapat dengan mudah dan cepat dimengerti oleh masyarakat umum, dan cukup sensitif untuk melihat perubahan status gizi dalam jangka waktu pendek. Selain itu pengukuran antropometrik dapat mendeteksi kegemukan (Soekirman, 2000).

Indikator $\mathrm{TB} / \mathrm{U}$ dapat menggambarkan status gizi masa lampau atau masalah gizi 
kronis. Seseorang yang pendek kemungkinan keadaan gizi masa lalu tidak baik. Berbeda dengan berat badan yang dapat diperbaiki dalam waktu singkat, baik pada anak maupun dewasa, maka tinggi badan pada usia dewasa tidak dapat lagi dinormalkan. Kemungkinan untuk mengejar pertumbuhan tinggi badan optimal pada anak balita masih bisa sedangkan anak usia sekolah sampai remaja kemungkinan untuk mengejar pertumbuhan tinggi badan masih bisa tetapi kecil kemungkinan untuk mengejar pertumbuhan optimal. Secara normal tinggi badan tumbuh bersamaan dengan bertambahnya umur. Pertambahan TB relatif kurang sensitif terhadap kurang gizi dalam waktu singkat. Pengaruh kurang gizi terhadap pertumbuhan TB baru terlihat dalam waktu yang cukup lama. Indikator ini juga dapat dijadikan indikator keadaan sosial ekonomi penduduk (Soekirman, 2000).

Indikator BB/TB merupakan pengukuran antropometri yang terbaik karena dapat menggambarkan secara sensitif dan spesifik status gizi saat ini atau masalah gizi akut. Berat badan berkorelasi linier dengan tinggi badan, artinya dalam keadaan normal perkembangan berat badan akan mengikuti pertambahan tinggi badan pada percepatan tertentu. Hal ini berarti berat badan yang normal akan proporsional dengan tinggi badannya. Ini merupakan indikator yang baik untuk menilai status gizi saat ini terutama bila data umur yang akurat sering sulit diperoleh. WHO dan UNICEF merekomendasikan menggunakan indikator $\mathrm{BB} / \mathrm{TB}$ dengan cut of point $<$ -3 Standar Deviasi (SD) dalam kegiatan identifikasi dan manajemen penanganan bayi dan anak balita gizi buruk akut.

Indikator indeks massa tubuh/usia (IMT/U) merupakan indikator yang paling baik untuk mengukur keadaan status gizi yang menggambarkan keadaan status gizi masa lalu dan masa kini karena berat badan memiliki hubungan linear dengan tinggi badan. Dalam keadaan normal, perkembangan berat badan akan searah dengan pertumbuhan tinggi badan dengan kecepatan tertentu. Indeks ini tidak menimbulkan kesan underestimate pada anak yang overweight dan obese serta kesan berlebihan pada anak gizi kurang (Anonim, 2013).

Panduan tata laksana penderita kurang energi protein (KEP) (Anonim, 2016) menyebutkan bahwa gizi buruk diartikan sebagai keadaan kekurangan gizi yang sangat parah yang ditandai dengan berat badan menurut umur kurang dari $60 \%$ median pada baku WHO-NCHS atau terdapat tandatanda klinis seperti marasmus, kwashiorkor dan marasmiks kwashiorkor. Agar penentuan klasifikasi dan penyebutan status gizi menjadi seragam dan tidak berbeda, maka Menteri Kesehatan (Menkes) RI mengeluarkan Keputusan Menteri Kesehatan Nomor 1995/Menkes/SK/XII/2010 tentang Standar Antropometri Penilaian Status Gizi Anak. Keluarnya SK tersebut mempermudah analisis data status gizi yang dihasilkan baik untuk perbandingan, kecenderungan maupun analisis hubungan (Anonim, 2016).

Status gizi sangat erat hubungannya dengan ketahanan pangan dimana keluarga yang ketahanan pangannya mencukupi, ratarata memiliki status gizi baik namun status gizi juga dilihat dari berapa besar rata-rata pengeluaran anggaran biaya untuk pangan suatu keluarga. Pengeluaran rata-rata per kapita adalah biaya yang dikeluarkan untuk konsumsi semua anggota rumah tangga (keluarga) selama sebulan dibagi dengan banyaknya anggota keluarga. Konsumsi rumah tangga dibedakan atas konsumsi makanan dan 
bukan makanan tanpa memperhatikan asal barang dan terbatas pada pengeluaran untuk kebutuhan rumah tangga saja, tidak termasuk konsumsi/pengeluaran untuk keperluan usaha atau yang diberikan kepada pihak lain. Pengeluaran untuk konsumsi makanan dihitung selama seminggu terakhir, sedangkan konsumsi bukan makanan dihitung sebulan dan tiga bulan terakhir. Baik konsumsi makanan maupun bukan makanan selanjutnya dikonversikan ke dalam pengeluaran rata-rata sebulan.

Berdasarkan Berat Badan menurut Umur diperoleh kategori: (1). Tergolong gizi buruk jika hasil pengukuran lebih kecil dari -3 SD. (2). Tergolong gizi kurang jika hasil pengukuran -3 SD - <-2 SD. (3). Tergolong gizi baik jika hasil pengukuran -2 SD - 2 SD. (4). Tergolong gizi lebih jika hasil pengukuran $>2 \mathrm{SD}$.

Berdasarkan pengukuran tinggi badan (24 bulan - 60 bulan) atau panjang badan ( 0 bulan - 24 bulan) menurut umur diperoleh 4 kategori: (1). Sangat pendek jika hasil penukuran lebih kecil -3 SD. (2). Pendek jika hasil pengukuran -3 SD - <-2 SD. (3). Normal jika hasil pengukuran -2 SD - 2 SD. (4). Tinggi jika hasil pengukuran $>2$ SD.

Berdasarkan pengukuran berat badan, menurut tinggi badan atau panjang badan dapat diperoleh 4 kategori: (1) Sangat kurus jika hasil pengukuran lebih kecil -3 SD. (2). Kurus jika hasil pengukuran -3 SD $-<-2$ SD. (3). Normal jika hasil pengukuran -2 SD - 2 SD. (4). Gemuk jika hasil pengukuran $>2$ SD. Balita dengan gizi buruk akan diperoleh hasil BB/TB sangat kurus, sedangkan balita dengan gizi baik akan diperoleh hasil normal.

Ketiga, kelompok rawan pangan dan gizi. Kelompok masyarakat yang rawan (vunerable) terhadap pangan dan gizi dapat dibedakan sesuai dengan (1). Lokasi tempat tinggalnya, disebut rawan ekologis, misalnya daerah terpencil. (2). Kedudukan/posisinya di masyarakat, disebut rawan sosio-ekonomis, misalnya kelompok miskin. (3). Umur dan jenis kelamin, disebut rawan biologis.

Secara biologis kelompok yang paling rawan terhadap kekurangan pangan atau gizi adalah bayi, balita dan anak sekolah, wanita hamil dan menyusui, penderita penyakit dan orang yang sedang dalam penyembuhan, penderita cacat, mereka yang diasingkan dan para jompo. Semua golongan ini sering kali dijumpai pada masyarakat miskin dan tidak memiliki lahan sumber pangan.

Di sektor pertanian, terdapat proporsi rumah tangga miskin yang sangat besar (72\%) dibandingkan dengan sektor lainnya. Kemiskinan inilah yang menjadi akar permasalahan dari ketidakmampuan keluarga untuk menyediakan pangan dalam jumlah, mutu, dan ragam yang sesuai dengan kebutuhan setiap individu untuk memenuhi asupan kebutuhan karbohidrat, protein, lemak, vitamin dan mineral yang bermanfaat bagi pertumbuhan dan perkembangan, serta kesehatan jasmani maupun rohani.

Keempat, prinsip gizi pada balita. Setelah anak berumur satu tahun menunya harus bervariasi untuk mencegah kebosanan dan diberi susu, serealia (seperti bubur beras, roti), daging, sup, sayuran dan buah-buahan. Makanan padat yang diberikan tidak perlu diblender lagi melainkan yang kasar supaya anak yang sudah mempunyai gigi dapat belajar mengunyah. Adakalanya anak tidak mau makan dan sebagai gantinya ibu memberikan susu. Kebiasaan demikian akan mengarah diet yang hanya terdiri dari susu saja. Jika anak tidak mau makan bentuk makanan padat, jangan diberikan susu sebagai pangganti, akan 
tetapi bawa pergi makanan itu dan coba lagi jika anak sudah lapar.

Anak di bawah umur 5 tahun (balita) merupakan kelompok yang menunjukkan pertumbuhan badan yang pesat, sehingga memerlukan zat-zat gizi yang tinggi setiap kilogram berat badannya. Anak balita ini justru merupakan kelompok umur yang paling sering menderita akibat kekurangan gizi. Gizi ibu yang kurang atau buruk pada waktu konsepsi atau sedang hamil muda dapat berpengaruh pada pertumbuhan seorang balita. Masa balita adalah masa pertumbuhan sehingga memerlukan gizi yang baik. Bila gizinya kurang itu akan berpengaruh pada kehidupannya di usia prasekolah dan sekolah.

Khususnya di wilayah Kabupaten Tangerang menunjukkan bahwa jumlah gizi buruk di Banten pada tahun 2014 mencapai 1.244 balita. Berdasarkan data dari Dinas Kesehatan (Dinkes) Banten hingga Desember 2014, jumlah gizi buruk berturut-turut di Kabupaten Tangerang 368 balita, Kabupaten Lebak 352 balita, Kabupaten Serang 201 balita, Kabupaten Pandeglang 115 balita, Kota Tangsel sebanyak 68 balita, Kota Serang 66 balita, Kota Tangerang 45 balita dan Kota Cilegon 29 balita. Hal ini menunjukkan bahwa jumlah tertinggi kasus balita gizi buruk terjadi di wilayah Kabupaten Tangerang dan terendah terjadi di wilayah Kota Cilegon (Anonim, 2016).

Pengertian gizi buruk sendiri adalah status gizi yang didasarkan pada indeks berat badan menurut umur $(\mathrm{BB} / \mathrm{U})<-3$ Standar Deviasi (SD) yang merupakan padanan istilah severely underweight 3 . Terdapat 3 jenis gizi buruk yang sering dijumpai yaitu kwashiorkor, marasmus dan gabungan dari keduanya yang lazim disebut marasmiks kwashiorkor. Pengertian kwashiorkor sendiri adalah suatu bentuk malnutrisi protein kategori berat yang disebabkan oleh asupan karbohidrat yang normal atau tinggi, namun asupan proteinnya tidak cukup. Kwashiorkor dapat dibedakan dengan marasmus yang disebabkan oleh asupan kurang jumlah tetapi kualitasnya normal, sedangkan marasmiks-kwashiorkor adalah gabungan dari kwashiorkor dengan marasmus yang disertai dengan "oedema" (pembengkakan) pada bagian kulit.

Berdasarkan hasil kajian oleh pertemuan International Scientific Symposyum on Measurement and Assessment of Food Deviation and Undernutrition, pada bulan Juni 2002 di Roma dan Nutrition in the Post 2015 Development Agenda tentang Seri Lancet Gizi tahun 2008 menunjukkan tindakan efektif untuk mengatasi kekurangan gizi. Meskipun kemajuan yang mantap dibuat dalam mengurangi kelaparan dan mencapai tujuan kemiskinan dan target, masih ada banyak yang harus dilakukan. Terdapat 5 metode yang lazim digunakan untuk mengukur kerawanan pangan dan kelaparan. Salah satunya adalah pengukuran kekurangan asupan gizi, kerawanan pangan melalui survei pendapatan atau pengeluaran rumah tangga untuk kecukupan pemenuhan kebutuhan pangan. Hasil survei pendapatan atau pengeluaran rumah tangga dapat digunakan untuk memperkirakan jumlah rata-rata konsumsi energi. Dalam survei pengeluaran responden ditanyakan mengenai pengeluaran untuk pangan dalam periode waktu tertentu seperti pengeluaran mingguan. Dapat dihitung proporsi pengeluaran rumah tangga untuk pemenuhan konsumsi energinya sampai kebutuhan di bawah minimum.

Penelitian ini merupakan penelitian deskriptif, dengan menggunakan rancangan penelitian kuantitatif dan kualitatif dengan 
metode penelitian cross sectional (potong lintang) karena pada penelitian ini variabel independen dan dependen diamati pada waktu (periode) yang sama. Rancangan penelitian deskriptif ini bertujuan untuk menerangkan atau menggambarkan ketahanan pangan keluarga dan hubungannya dengan status gizi balita serta upaya peningkatan ketahanan pangan.

Pendekatan yang dilakukan dalam penelitian ini menggunakan pendekatan kuantitatif dan kualitatif, kemudian teknik penelitian yaitu survei dan observasi ke lapangan.

Lokasi Penelitian dilaksanakan di Desa Palasari, Kecamatan Legok, Kabupaten Tangerang dan Puskesmas Legok. Puskesmas ini dipilih karena Desa Palasari termasuk desa rawatan dari Puskesmas Legok dimana terdapat banyak anak yang mengalami gizi buruk dan gizi kurang sehingga akan berpengaruh terhadap pertumbuhan dan perkembangan anak.

Pengumpulan data dilakukan secara langsung dengan memberikan kuesioner kepada Ibu/orang tua dengan anak balita di Desa Palasari dan Puskesmas Legok Kecamatan Legok Kabupaten Tangerang dengan prosedur sebagai berikut: (1). Langkah awal yang dilakukan peneliti adalah melakukan observasi pendahuluan mengenai ketahanan pangan dan status gizi balita di Desa Palasari dan Puskesmas Legok Kabupaten Tangerang yang dipilih sebagai tempat pelaksanaan penelitian. (2). Peneliti melakukan pendekatan pada masing-masing responden yang memenuhi kriteria sampel dan untuk memperoleh kesediaannya menjadi responden penelitian dan kemudian diberikan kuesioner untuk diisi. (3). Selain kuesioner, peneliti juga mengadakan wawancara dengan pihak Puskesmas, Aparat Desa dan Masyarakat Desa Palasari, Kecamatan Legok, Kabupaten Tangerang. (4). Peneliti juga mengumpulkan dokumen-dokumen terkait ketahanan pangan dan status gizi balita di Desa Palasari serta Puskesmas Legok, Kabupaten Tangerang yang dipilih sebagai tempat pelaksanaan penelitian.

Hasil penelitian ini diharapkan dapat menemukan hubungan antara ketahanan pangan keluarga dengan status gizi balita, dan bertujuan untuk mengkaji hubungan antara ketahanan pangan dan status gizi balita di wilayah kerja Puskesmas Legok, Kecamatan Legok, Kabupaten Tangerang dan mendapatkan upaya untuk mengatasi gizi buruk tersebut di atas melalui gerakan peningkatan ketahanan pangan. Guna mendapatkan data yang memadai maka peneliti melakukan pengumpulan data berupa data primer dan data sekunder. Data primer terdiri atas hasil kuesioner, observasi dan wawancara di Desa Palasari dan Puskesmas Legok serta pihakpihak terkait. Data sekunder terdiri atas data demografi, geografi, dan laporan tahunan penanggulangan gizi buruk dan kurang gizi dari Puskesmas di Kecamatan Legok, Kabupaten Tangerang.

\section{PEMBAHASAN}

\section{Karakteristik Rumah Tangga}

Karakteristik responden merupakan gambaran secara umum tentang keadaan responden. Pada penelitian ini diambil 100 responden di Desa Palasari, Kecamatan Legok, Kabupaten Tangerang yang bertempat tinggal di 3 dusun. Karakteristik rumah tangga responden meliputi data-data tentang usia, pendidikan, pekerjaan, jumlah anggota keluarga dan penghasilan. Sebagian besar responden penelitian berusia 41-60 tahun yaitu sebanyak 56 orang, berusia 21 - 40 tahun 
sebanyak 44 orang, sedangkan yang berusia 60 tahun ke atas tidak bersedia untuk menjadi responden peneliti dikarenakan sudah usia lanjut.

Untuk mengetahui tingkat pendidikan, di Desa Palasari yang berpendidikan SD 16 orang, SMP 61 orang, dan SMA 21 orang, sedangkan sisanya tidak bersekolah sama sekali yaitu 2 orang.

Dari jenis pekerjaan utama yang dimiliki responden terdapat beberapa macam pekerjaan. Responden yang memiliki pekerjaan utama sebagai buruh 41 orang, pegawai 7 orang, guru 4 orang, wiraswasta 1 orang, pedagang 1 orang, lainnya 6 orang, menganggur 40 orang. Masyarakat yang tidak memiliki keterangan pekerjaan dikarenakan tidak memiliki pekerjaan tetap. Masih banyak masyarakat Desa Palasari yang tidak punya pekerjaan tetap tersebut. Kondisi ini harusnya menjadi perhatian bagi Pemerintah Daerah untuk menyiapkan lapangan pekerjaan buat mereka. Namun demikian, faktor lain menunjukkan bahwa banyaknya masyarakat tidak bisa bekerja di sebabkan karena rendahnya tingkat pendidikan mereka sehingga tidak memenuhi persyaratan untuk bekerja di sebuah intansi atau perusahaan.

Kemudian jumlah anggota keluarga responden yang tinggal dalam satu rumah sangat bervariasi jumlah anggotanya, anggota keluarga 4-5 orang sebanyak 58 orang, anggota keluarga 6-7 orang sebanyak 27 orang, anggota keluarga $\leq 3$ sebanyak 12 orang, sedangkan sisanya memiliki anggota keluarga lebih dari 7 orang sebanyak 3 orang.

Dari segi pendapatan bulanan yang diterima responden juga bervariasi besarnya, sebagian besar responden memiliki pendapatan $\leq$ Rp 600.000,- per bulan sebanyak 3 orang, pendapatan $R p 600.000$ sampai dengan $R p$
1.000.000,- per bulan sebanyak 8 orang, pendapatan Rp 1.000.000,- sampai dengan Rp 2.000.000,-- per bulan sebanyak 78 orang, pendapatan Rp 2.000.000,- sampai dengan Rp 3.000.000,- per bulan sebanyak 9 orang, dan pendapatan $\geq \operatorname{Rp} 3.000 .000$,- per bulan sebanyak 2 orang (UMP Kabupaten Tangerang). Data tersebut menunjukan bahwa banyak responden yang masih memiliki pendapatan rendah sehingga cukup sulit untuk pemenuhan kebutuhan keluarga.

\section{Identifikasi Sumber Pangan}

Bahan pangan untuk konsumsi seharihari dapat dikelompokkan menjadi 9 kelompok besar. Jenis pangan pada masing-masing kelompok dapat berbeda-beda pada setiap rumah tangga sesuai sumber pangan yang tersedia. Secara nasional bahan pangan dikelompokkan sebagai berikut: (1) Padipadian: beras, jagung, sorgum dan terigu (2) Umbi-umbian: ubi kayu, ubi jalar, kentang, talas, sagu, dan umbi lainnya (3) Pangan hewani: ikan, daging, susu dan telur (4) Minyak dan lemak: minyak kelapa, minyak sawit (minyak goreng, minyak jagung, margarin) (5) Buah/biji berminyak: kelapa, kemiri, jambu mete dan coklat (6) Kacangkacangan: kedelai, kacang tanah, kacang hijau, kacang merah, dan kacang lainnya (7) Gula: gula pasir, gula merah (8) Sayur dan buah: semua jenis sayuran dan buah-buahan yang biasa dikonsumsi (9) Lain-lain: teh, kopi, sirup, bumbu-bumbuan, makanan dan minuman jadi.

\section{Pedoman Umum Gizi Seimbang (PUGS)}

Penjabaran dari menu seimbang 4 sehat 5 sempurna memiliki konsep dasar gizi seimbang, yaitu (1). Menu yang dianjurkan adalah yang menjamin keseimbangan zat-zat 


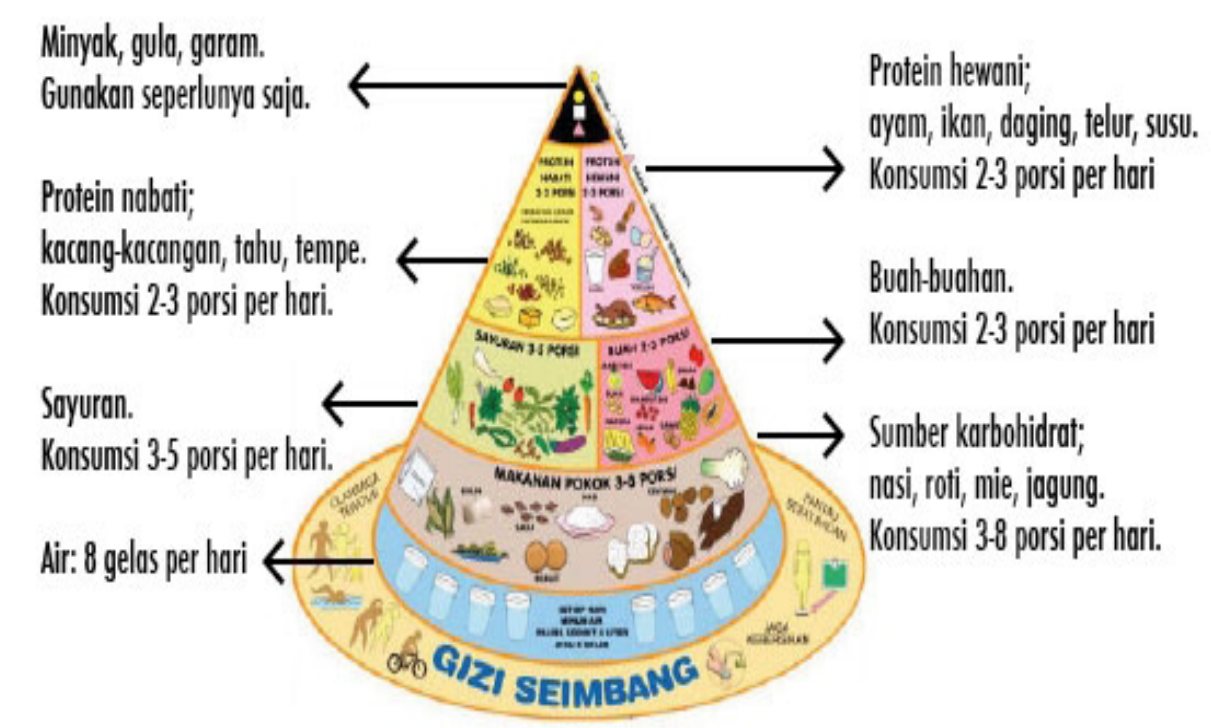

Sumber : Depkes, 2013.

gizi. (2). Tiap bahan makanan dapat saling melengkapi mengkonsumsi beraneka ragam makanan setiap harinya. (3). Bahan makanan dikelompokkan pada 3 fungsi utama, yaitu (a). Sumber energi: makanan pokok (nasi, jagung, terigu, umbi, sagu dll.), (b). Sumber zat pembangun : lauk-pauk (daging, ayam,telur, susu, tempe, tahu, kacang-kacangan), (c). Sumber zat pengatur : sayuran dan buahbuahan untuk mencapai gizi seimbang menu sehari harus terdiri dari campuran ke-3 kelompok bahan makanan tersebut.

Konsep dasar 4 sehat 5 sempurna (basic four) mengalami perubahan menjadi Nutrition Guide For Balanced Diet di Indonesia menjadi Pedoman Gizi Seimbang, disingkat (PGS) dengan visualisasi dalam bentuk tumpeng yang secara umum mengikuti visualisasi piramida yang dipakai oleh Amerika Serikat. Kebijakan nasional tersebut ditindaklanjuti oleh Departemen Kesehatan dengan mengeluarkan Pedoman Umum Gizi
Seimbang (PUGS) yang berisi 13 pesan dasar gizi seimbang. Nutrition Guide For Balanced Diet adalah pedoman bagi kelompok umur di atas 2 tahun, sementara PUGS dalam bentuk 13 pesan dasar umum adalah pedoman bagi semua umur mulai dari nol bulan hingga kelompok usia lanjut dengan memasukan Air Susu Ibu (ASI) ekslusif sebagai gizi seimbang bagi bayi berumur 0-6 bulan (Anonim, 2013).

Pedoman Umum Gizi Seimbang (PUGS) memuat 13 pesan dasar pedoman praktis, yaitu (1). Makanlah aneka ragam makanan, (2). Makanlah makanan untuk memenuhi kecukupan energi, (3). Makanlah makanan sumber $\mathrm{KH}$, setengah dari kebutuhan energi, (4). Batasi konsumsi lemak/minyak sampai seperempat dari kebutuhan energi, (5). Gunakan garam beriodium, (6). Makanlah makanan sumber zat besi, (7). Berikan ASI saja kepada bayi sampai umur 6 bulan, (8). Biasakan makan pagi, (9). Minumlah air bersih, aman dan cukup jumlahnya, (10). 
Lakukan kegiatan fisik dan olah raga secara teratur, (11). Hindari minuman beralkohol, (12). Makanlah makanan yang aman bagi kesehatan, (13). Bacalah label pada makanan yang dikemas

Indonesia memasukkan unsur budaya dalam memilih bentuk visualisasi panduan gizi bagi masyarakat, sehingga kemudian sampai pada pilihan bentuk tumpeng yang menyerupai topi perayaan tahun baru, sebagaimana ditunjukkan gambar 1 di atas.

Konsepnya hampir sama dengan konsep pada bentuk piramida yang sebelumnya digunakan oleh Indonesia, yaitu terdapat 6 kelompok pangan, dimana paling bawah adalah kelompok makanan pokok (porsinya paling besar), disusul sayur, buah, protein nabati dan hewani, serta paling sedikit adalah minyak, gula dan garam. Bedanya dengan bentuk terdahulu, pada tumpeng gizi seimbang ini dilengkapi dengan anjuran minum air putih dan anjuran pola hidup sehat, yaitu berolah raga teratur atau aktivitas fisik, menjaga kebersihan dan memantau berat badan secara teratur.

\section{Konsumsi Kalori Rumah Tangga}

Sebelum menghitung konsumsi kalori setiap rumah tangga responden, maka dihitung terlebih dahulu bahan pangan yang dikonsumsi oleh masing-masing responden rumah tangga. Ini meliputi hampir semua makanan dan minuman mengandung kalori, tetapi dengan jumlah kalori yang berbeda, dimana zat gizi utama penyusun makanan adalah karbohidrat, protein, lemak serta vitamin dan mineral. Semua ini mempengaruhi kandungan kalori makanan dan minuman.

Konsumsi kalori setiap rumah tangga dihitung berdasarkan jenis pangan yang dikonsumsi per minggu oleh rumah tangga responden yang dikonversikan menjadi kalori. Konversi satuan ukuran rumah tangga dihitung ke dalam satuan berat (gram). Berdasarkan tabel konversi konsumsi pangan kemudian dapat dihitung jumlah kalori yang dikonsumsi setiap orang anggota keluarga per hari dengan cara membagi total konsumsi kalori KK per minggu dengan jumlah anggota keluarga yang ada. Konsumsi energi per hari per orang berdasarkan rekomendasi Widyakarya Nasional Pangan dan Gizi IX 2008 adalah sebesar $2.200 \mathrm{kkal} /$ orang/hari. Konsumsi kalori per anggota keluarga per hari dapat digolongkan seperti disajikan pada tabel 1 berikut.

Tabel 1

Perhitungan Penggolongan Konsumsi Kalori Per Orang Per Hari

\begin{tabular}{cccc}
$\begin{array}{c}\text { Energi } \\
\text { (Kkal/ org/hari) }\end{array}$ & Kategori & Orang & $\%$ \\
\hline$\leq 2200$ & Kurang & 46 & 46 \\
\hline$>2200$ & Cukup & 54 & 54 \\
\hline Jumlah & & 100 & 100 \\
\hline
\end{tabular}

Sumber: Hasil olahan sendiri

Tabel 1 tersebut menjelaskan bahwa sebagian besar KK responden penelitian memiliki konsumsi kalori lebih dari 2200 kkal/orang/hari, yaitu 54 KK (54\%). Sedangkan sisanya $46 \mathrm{KK}$ responden penelitian (46\%) mengkonsumsi energi $\leq 2200 \mathrm{kkal} /$ orang /hari. Secara rata-rata responden penelitian memiliki tingkat konsumsi kalori sebesar 3075,10 kkal/orang/ hari, sehingga dapat dihitung besaran TKE $=3075,10: 2.200 \times 100 \%=103,97 \%$. Angka TKE sebesar 103,97 \% atau > 80\%, merupakan Angka Kecukupan Gizi (AKG) yang dianjurkan. Oleh karena itu secara asupan kalori rata-rata maka Desa Palasari merupakan desa masuk kategori tidak rawan pangan. 


\section{Pangsa Pengeluaran Pangan Bagi Rumah Tangga}

Pengeluaran total merupakan pengeluaran untuk konsumsi pangan ditambah pengeluaran untuk non pangan. Data pengeluaran pangan, pengeluaran non pangan dan total pengeluaran didistribusikan berdasarkan pangsa pengeluaran pangan yang disajikan pada tabel 2 berikut.

Tabel 2

Perhitungan Penggolongan Konsumsi Kalori Per Orang Per Hari

\begin{tabular}{cccc}
$\begin{array}{c}\text { Pangsa pengeluaran } \\
\text { pangan }\end{array}$ & Kategori & Orang & $\%$ \\
\hline$\leq 60 \%$ & Rendah & 25 & 25 \\
\hline$>60 \%$ & Tinggi & 75 & 75 \\
\hline Jumlah & & 100 & 100 \\
\hline
\end{tabular}

Sumber: Hasil olahan sendiri

Tabel 2 tersebut menjelaskan bahwa mayoritas KK responden penelitian memiliki pangsa pengeluaran pangan lebih dari $60 \%$ per bulan sebesar $75 \%$ dan hanya sebagian KK responden penelitian yang memiliki pangsa pengeluaran pangan kurang dari $60 \%$ sebesar $25 \%$. Secara rata-rata responden penelitian memiliki pangsa pengeluaran pangan sebesar Rp. 1.006.360,- per bulan, sementara total pengeluaran rata-rata sebesar Rp. 1.424.493,- sehingga perhitungan pangsa pengeluaran pangan (PP) adalah sebagai berikut.

$$
\begin{aligned}
P F & =\frac{P P}{T P} \times 100 \% \\
& =\frac{\operatorname{Rp~} 1.006 .360,-}{\operatorname{Rp~} 1.424 .493,-} \times 100 \%=69,42 \%
\end{aligned}
$$

Catatan: $\mathrm{PF}=$ Pangsa Pengeluaran Pangan (\%), PP = Pengeluaran Pangan (Rupiah), TP $=$ Total Pengeluaran Rumah Tangga (Rupiah)

Perhitungan PF menunjukkan bahwa pangsa pengeluaran rumah tangga ratarata responden penelitian adalah sebesar $69,42 \%$. Angka ini $>60 \%$ yang berarti Desa Palasari merupakan desa yang rawan pangan. Hal lainnya juga adalah bahwa rumah tangga responden lebih mengutamakan pendapatannya untuk memenuhi kebutuhan dasarnya terlebih dahulu, yakni berupa pangan, apabila kebutuhan dasar tersebut sudah terpenuhi, maka keluarga akan mengalokasikan pendapatannya untuk kebutuhan non pangan

\section{Tingkat Ketahanan Pangan Rumah Tangga Desa Palasari}

Pada penelitian ini difokuskan untuk melihat pengaruh konsumsi energi dan pangsa pengeluaran pangan terhadap tingkat ketahanan pangan rumah tangga, dimana pola konsumsi merupakan salah satu alat ukur untuk melihat ketahanan pangan rumah tangga. Kriteria ketahanan pangan rumah

Tabel 3

Tingkat ketahanan Pangan Rumah Tangga Desa Palasari

\begin{tabular}{lcc}
\hline \multirow{2}{*}{$\begin{array}{c}\text { Konsumsi energi per unit ekuivalen } \\
\text { dewasa }\end{array}$} & \multicolumn{2}{c}{ Pangsa Pengeluaran Pangan } \\
\cline { 2 - 3 } & $\begin{array}{c}\text { Rendah } \\
(\leq 60 \% \text { pengeluaran total })\end{array}$ & $\begin{array}{c}\text { Tinggi } \\
(>60 \% \text { pengeluaran total })\end{array}$ \\
\hline $\begin{array}{l}\text { Cukup }(>80 \% \text { syarat kecukupan } \\
\text { energi) }\end{array}$ & $\begin{array}{c}\text { Tahan pangan } \\
(15 \%)\end{array}$ & $\begin{array}{c}\text { Rentan pangan } \\
(39 \%)\end{array}$ \\
\hline $\begin{array}{l}\text { Kurang }(\leq 80 \% \text { syarat kecukupan } \\
\text { energi })\end{array}$ & $\begin{array}{c}\text { Kurang pangan } \\
(10 \%)\end{array}$ & $\begin{array}{c}\text { Rawan pangan } \\
(36 \%)\end{array}$ \\
\hline
\end{tabular}

Sumber: Hasil olahan sendiri 
tangga dapat diklasifikasikan berdasarkan tingkat konsumsi energi per unit ekuivalen dewasa dengan pangsa pengeluaran pangan seperti disajikan pada tabel 3 di atas.

Tabel 3 di atas menjelaskan bahwa sebagian besar responden penelitian berada dalam kategori rawan pangan, yaitu sebanyak $36 \%$, kategori rentan pangan sebanyak $39 \%$ dan kategori tahan pangan sebanyak $15 \%$, serta kategori kurang pangan sebanyak $910 \%$.

Hubungan ketahanan pangan keluarga dan status gizi balita di Desa Palasari Kecamatan Legok Kabupaten Tangerang dapat dilihat pada tabel 4 berikut.

Tabel 4 tersebut menjelaskan bahwa sebagian besar keluarga yang rentan dan rawan pangan memiliki balita dengan status gizi buruk dan kurang yaitu 47 balita dan memiliki status gizi baik 38 balita. Sementara keluarga yang tahan pangan sebagian besar memiliki status gizi yang baik yaitu sebanyak 13 balita dan yang memiliki status gizi buruk dan kurang 2 orang. Kondisi ini menunjukkan bahwa di dalam keluarga yang rentan dan rawan pangan belum tentu semuanya memiliki status gizi buruk dan kurang namun banyak juga yang mengalami status gizi yang baik, begitu juga sebaliknya. Dalam keluarga yang tahan pangan belum tentu status gizinya baik semuanya, ada juga yang sebagian memiliki status gizi buruk dan kurang hal ini dikarenakan banyak faktor, yaitu pola asuh dari orang tua, pendidikan dan pengetahuan orang tua, jumlah anggota keluarga, pendapatan dan pengeluaran kebutuhan rumah tangganya serta pemberian asupan makanan yang bergizi bagi balita.

Faktor yang mempengaruhi terjadinya gizi buruk adalah status sosial ekonomi, ketidaktahuan ibu tentang pemberian gizi yang baik untuk anak dan berat badan lahir rendah (BBLR). Melalui uji korelasi, dapat ditunjukkan adanya hubungan yang positif dan signifikan antara pekerjaan ibu dengan status gizi balita. Sumber lain mengatakan bahwa rendahnya pendidikan dapat mempengaruhi ketersediaan pangan dalam keluarga, yang selanjutnya mempengaruhi kuantitas dan kualitas konsumsi pangan yang merupakan penyebab langsung dari kekurangan gizi pada anak balita (Kosim, 2008).

Teori konsumsi Keynes dalam bukunya yang berjudul The General Theory of Employment, Interest and Money menjelaskan adanya hubungan antara pendapatan yang diterima saat ini (pendapatan disposabel) dengan konsumsi yang dilakukan saat ini juga. Dengan kata lain pendapatan yang dimiliki dalam suatu waktu tertentu akan mempengaruhi konsumsi yang dilakukan oleh manusia dalam waktu itu juga. Apabila pendapatan meningkat maka konsumsi yang dilakukan juga akan meningkat, begitu pula sebaliknya (Pujoharso, 2013).

Tabel 4

Silang Hubungan Ketahanan Pangan Keluarga Dan Status Gizi Balita

\begin{tabular}{cccc}
\multirow{2}{*}{ Ketahanan pangan } & \multicolumn{2}{c}{ Status gizi } & \multirow{2}{*}{ Total } \\
\cline { 2 - 3 } Rentan dan Rawan Pangan & Gizi Buruk dan Kurang (\%) & Gizi baik (\%) & 85 \\
\hline Tahan Pangan & 47 & 38 & 13 \\
\hline Total & 2 & 51 & 100 \\
\hline
\end{tabular}

Sumber: Hasil olahan sendiri 
Penelitian yang dilakukan Halik (2007) menunjukkan faktor dominan yang mempengaruhi tingkat ketahanan pangan adalah luas lahan, tingkat pendapatan per kapita, dan tingkat pendidikan kepala rumah tangga. Hubungan antara tingkat ketahanan pangan dengan status gizi masyarakat menunjukkan tingkat ketahanan pangan masyarakat pedesaan cukup tahan, namun ternyata status gizi masyarakat masih rendah sebagai akibat dari masih rendahnya pemahaman masyarakat akan persoalan pangan dan gizi khususnya para ibu rumah tangga, sehingga mereka belum dapat memanfaatkan apa yang dimilikinya secara optimal.

Tingkat pendidikan formal merupakan faktor yang ikut menentukan mudah tidaknya seseorang menyerap dan menekuni pengetahuan yang diperoleh.Masukan gizi anak sangat tergantung pada sumber-sumber yang ada di lingkungan sosialnya, salah satu yang menentukan adalah ibu. Peranan orang tua, khususnya ibu, dalam menyediakan dan menyajikan makanan bergizi bagi keluarga, khususnya anak menjadi penting. Kualitas pelayanan ibu dalam keluarga ditentukan oleh penguasaan informasi dan faktor ketersediaan waktu yang memadai. Kedua faktor tersebut merupakan faktor determinan yang dapat ditentukan dengan tingkat pendidikan, interaksi sosial dan pekerjaan.

Status Gizi pada balita secara langsung atau tidak langsung dipengaruhi oleh kecerdasan intelektual ibu yang rendah, tingkat pendidikan orang tua (ibu dan ayah yang rendah), kemiskinan atau status social ekonomi, lingkungan tempat tinggal, status pengasuhan anak yang memadai, keyakinan budaya, dan akses ke tempat penyedia pelayanan kesehatan (Ramli, et al., 2009).
Kerawanan pangan dapat berakibat langsung pada rendahnya status gizi dan akan berdampak buruk bagi kesehatan anggota rumah tangga. Dampak lebih lanjut pada anak-anak balita dan anak usia sekolah dapat mengakibatkan penurunan daya ingat. Untuk itu, rumah tangga dengan kategori rawan pangan yang secara ekonomi kurang memiliki kemampuan, sebaiknya diarahkan kepada peningkatan pendapatan sebagai usaha meningkatkan kesejahteraan rumah tangga agar dapat mengkonsumsi pangan baik sumber karbohidrat, lemak, protein, vitamin maupun mineral. Peningkatan pengetahuan tentang pangan dan gizi juga diperlukan agar lebih dapat menganekaragamkan jenis dan meningkatkan mutu pangan, baik dari segi kuantitas maupun kualitas.

Status gizi (nutritional status) merupakan outcome ketahanan pangan yang merupakan cerminan dari kualitas hidup seseorang. Banyaknya balita yang mengalami kurang gizi dan gizi buruk merupakan indikator rawan gizi, sedangkan gizi buruk dipengaruhi oleh banyak faktor yang saling terkait. Penyebab hal tersebut adalah konsumsi makanan yang tidak seimbang dan penyakit infeksi (akut) sebagai akibat tidak cukup persediaan pangan dan pola asuh anak tidak memadai, serta sanitasi/ air bersih, dan pelayanan kesehatan dasar tidak memadai (Anonim, 2013).

Penelitian yang dilakukan di Desa Palasari menunjukkan adanya status gizi buruk dan kurang serta status gizi baik, sebagai akibat dari dari bagaimana suatu keluarga menerapkan suatu prinsip hidup sehat dengan status gizi baik. Ditemukan dalam keluarga yang rentan dan rawan pangan banyak terdapat balita yang status gizinya baik, sebaliknya dalam keluarga yang tahan pangan juga ditemukan balita yang status 
gizinya kurang. Kesimpulannya, status gizi ini dipengaruhi oleh beberapa faktor yaitu (1) Pangan yang cukup, (2) Pendapatan keluarga, (3) Pendidikan orang tua, (4) Pola asuh anak/ balita, (5) Konsumsi makanan bergizi.

Upaya yang dilakukan untuk meningkatkan ketahanan pangan dalam masyarakat adalah meningkatkan kemandirian masyarakat untuk berperan aktif dalam mewujudkan ketersediaan, distribusi dan konsumsi pangan dari waktu ke waktu. Pembangunan ketahanan pangan pada hakikatnya adalah masyarakat yang terlibat dalam pembangunan ketahanan pangan meliputi produsen, pengusaha, konsumen, aparatur pemerintah, perguruan tinggi, dan lembaga swadaya masyarakat.

Berbagai upaya pemberdayaan untuk peningkatan kemandirian masyarakat khususnya pemberdayaan petani dapat dilakukan melalui:

Pertama, pemberdayaan dalam pengembangan untuk meningkatkan produktivitas dan daya saing. Hal ini dapat dilaksanakan melalui kerjasama dengan penyuluh dan peneliti. Teknologi yang dikembangkan harus berdasarkan spesifik lokasi yang mempunyai keunggulan dalam kesesuaian dengan ekosistem setempat dan memanfaatkan input yang tersedia di lokasi serta memperhatikan keseimbangan lingkungan.

Kedua, penyediaan fasilitas kepada masyarakat hendaknya tidak terbatas pengadaan sarana produksi, tetapi dengan sarana pengembangan agrobisnis lain yang diperlukan seperti informasi pasar, peningkatan akses terhadap pasar, permodalan serta pengembangan kerjasama kemitraan dengan lembaga usaha lain.

Ketiga, revitalitasasi kelembagaan dan sistem ketahanan pangan masyarakat. Hal ini bisa dilakukan melalui pengembangan lumbung pangan. Pemanfaatan potensi bahan pangan lokal dan peningkatan spesifik berdasarkan budaya lokal sesuai dengan perkembangan selera masyarakat yang dinamis

Dalam upaya mewujudkan ketahanan pangan, peran dan partisipasi masyarakat khsususnya kelembagaan tani, kelembagaan pedesaan lainnya, serta aparatur (stakeholder pembangunan ketahanan pangan) perlu mendapatkan perhatian dari pemerintah. Hal ini disebabkan karena masalah pangan menjadi tanggung jawab unsur pemerintah, swasta maupun masyarakat lainnya.

Untuk lebih menumbuhkan motivasi dan mengoptimalkan partisipasi aparatur, lembaga swasta dan masyarakat lainnya, perlu ada gerakan-gerakan yang mampu meningkatkan kinerja lembaga-lembaga tersebut dalam upaya mewujudkan ketahanan pangan sesuai dengan perannya masing-masing. Salah satu cara untuk memotivasi kelompok tani, lembaga pedesaan (Koperasi Tani, KUD, dan sebagainya) dan aparatur pelayanan agar lebih efektif berpartisipasi dalam pelaksanaan program peningkatan produksi dan produktivitas usaha tani, adalah dengan penyelenggaraan perlombaan ketahanan pangan. Perlombagaan ini telah diyakini sebagai salah satu sarana untuk meningkatkan motivasi dan partisipasi petani secara aktif agar petani mau dan mampu meningkatkan produksi dalam rangka mewujudkan ketahanan pangan.

Pemberdayaan masyarakat juga merupakan suatu proses mengajak atau membawa masyarakat agar mampu melakukan sesuatu (enabling people to do something). Sasaran pemberdayaan masyarakat tersebut mencakup para keluarga petani, buruh, pedagang kecil lain yang selama ini dikenal 
sebagai kelompok tertinggal, bahkan pemerintah itu sendiri.

Lebih lanjut, strategi pencegahan dan penanggulangan gizi buruk di masyarakat dapat dilakukan dengan: (1) Mengembalikan fungsi posyandu dan meningkatkan kembali partisipasi masyarakat dan keluarga dalam memantau, mengenali dan menanggulangi secara dini gangguan pertumbuhan pada balita. (2) Meningkatkan kemampuan dan keterampilan SDM Puskesmas beserta jaringannya dalam tatalaksana gizi buruk dan masalah gizi lain, manajemen laktasi dan konseling gizi. (3) Menanggulangi secara langsung masalah gizi yang terjadi pada kelompok rawan gizi termasuk keadaan darurat melalui suplementasi zat gizi mikro, MP-ASI, makanan tambahan dan diet khusus. (4) Mewujudkan keluarga sadar gizi melalui advokasi, sosialisasi dan KIE gizi seimbang. (5) Mengoptimalkan surveilans berbasis masyarakat melalui SKDN, Sistem Kewaspadaan Dini Kejadian Luar Biasa (SKDKLB) Gizi Buruk, dan Sistem Kewaspadaan Pangan dan Gizi (SKPG), untuk meningkatkan manajemen program perbaikan gizi. (6) Mengembangkan model intervensi gizi tepat guna yang evidence based. (7) Menggalang kerjasama lintas sektor dan kemitraan dengan masyarakat beserta swasta/dunia usaha dalam memobilisasi sumberdaya untuk penyediaan pangan di tingkat rumah tangga, peningkatan daya beli keluarga, dan perbaikan pola asuhan gizi keluarga.

Sejalan dengan permasalahan, peluang dan paradigma baru pemantapan ketahanan pangan, strategi yang dikembangkan dalam upaya pemantapan ketahanan pangan adalah:

Pertama, pengembangan kapasitas produksi pangan nasional melalui rehabilitasi kemampuan, optimalisasi pemantapan dan pelestarian sumber daya alam yaitu: lahan, air dan perairan.

Kedua, peningkatan pemberdayaan dan partisipasi masyarakat menuju terwujudnya ketahanan pangan rumah tangga, serta perilaku sadar gizi.

Ketiga, pengembangan agribisnis pangan yang berdaya saing, berkerakyatan, berkelanjutan, dan tersentralisasi dengan pengertian: (1). Berdaya saing tinggi, yang diupayakan melalui peningkatan efisiensi dengan memanfaatkan inovasi dan teknologi, peningkatan produktivitas dan nilai tambah, serta penajaman orientasi pasar. (2). Berkerakyatan, yaitu memfasilitasi peluang yang lebih besar bagi masyarakat luas untuk berpartisipasi dalam usaha kecil dan menengah, dengan mendayagunakan sumber daya yang dimilikinya. (3). Berkelanjutan, diupayakan melalui peningkatan dan pemeliharaan kapasitas sumber daya alam, penerapan teknologi ramah lingkungan dan pengembangan sistem distribusi keuntungan yang adil. (4). Tersentralisasi, yang berarti keputusan tentang hal-hal yang terkait dengan pengelolaan sumber daya daerah untuk meningkatkan ketahanan pangan berada di tangan masyarakat bersama Pemerintah Daerah, dalam rangka mendorong pendayagunaan keunggulan sumber daya daerah sesuai referensi masyarakat di daerah yang bersangkutan.

Keempat, pengembangan dan peningkatan intensitas jaringan kerjasama lintas pelaku, lintas wilayah dan lintas waktu dalam suatu sistem koordinasi guna mensinergikan kebijakan, program dan kegiatan pemantapan ketahanan pangan.

Kelima, peningkatan efektivitas dan kualitas kinerja pemerintah dalam menfasilitasi masyarakat berpartisipasi dalam pemantapan ketahanan pangan (Hariyadi, 2010) 
Salah satu fungsi utama program perbaikan gizi masyarakat di Puskesmas adalah mempersiapkan, memelihara dan mempertahankan agar setiap orang mempunyai status gizi baik, dapat hidup sehat dan produktif. Fungsi ini dapat terwujud kalau setiap petugas dalam melaksanakan program gizi dilakukan dengan cara yang baik dan benar sesuai komponen-komponen yang harus ada dalam program perbaikan gizi masyarakat di Puskesmas. Program peningkatan gizi yang dilaksanakan oleh Puskesmas Legok ada yang bersifat harian, yaitu peningkatan pemberian ASI eklusif tanpa makanan dan minuman lain pada bayi berumur 0 sampai 6 bulan, kemudian bersifat bulanan, yaitu pemantauan pertumbuhan berat badan balita (penimbangan balita) dalam bentuk pengukuran berat badan balita untuk mengetahui pola pertumbuhan dan pengembangan berat badan balita, dan ada yang bersifat tahunan, yaitu pemantauan status gizi balita, dan pemantauan konsumsi gizi.

Dengan adanya program peningkatan gizi tersebut diharapkan dapat mencapai status rumah tangga yang tahan pangan, dalam arti kebutuhan pangan seluruh anggota rumah tangga terpenuhi dalam jumlah yang cukup dan terjamin mutunya. Diharapkan ini dapat meningkatkan pola pengasuhan anak, dan keluarga pun makin banyak memanfaatkan pelayanan kesehatanan yang ada dengan sebaik-baiknya, sehingga dapat tercapai status gizi anak secara optimal baik fisik, mental maupun sosial.

\section{SIMPULAN}

Berdasar penjelasan tersebut di atas dapat ditarik simpulan sebagai berikut.

Pertama, ketahanan pangan dan status gizi balita mempunyai hubungan yang erat, jika keluarga kekurangan pangan maka akan mempengaruhi status gizi keluarga tersebut.

Kedua, upaya untuk mengatasi masalah status gizi diperoleh dengan melaksanakan program harian, bulanan dan tahunan. Hal tersebut merupakan program dari Puskesmas Legok untuk meningkatkan perbaikan gizi balita dan keluarga.

Selanjutnya direkomendasikan hal-hal sebagai berikut.

Pertama, ada terobosan baru dalam bentuk pemberdayaan rumah tangga secara sistematis dan terstruktur yang nantinya dapat mengatasi permasalahan ketahanan pangan keluarga dan status gizi balita masyarakat.

Kedua, pemerintah bersama kelompok masyarakat agar meningkatkan upaya ketahanan pangan untuk mengatasi gizi buruk dan kurang.

\section{DAFTAR PUSTAKA}

Anonim. 2016. Kab. Tangerang Terbanyak Kasus Gizi Buruk, diakses dari http:// satelitnews.co.id/2015/03/03/kabtangerang-terbanyak-kasus-gizi-buruk-

Anonim. 2013. Riset Kesehatan Dasar (RISKESDAS). Badan Penelitian dan Pengembangan Kesehatan Jakarta.

Anonim. 2013. Direktorat Jenderal Bina Gizi dan KIA Kementerian Kesehatan RI.

Anonim. 2016. Buku Saku Pemantauan Status Gizi Dan Indikator Kinerja Gizi Tahun 2015, Direktorat Gizi Masyarakat Direktorat Jenderal Kesehatan Masyarakat, Kementerian Kesehatan RI.

Ariani, M. dan Pitono, J. 2014. Diversifikasi Konsumsi Pangan: Kinerja dan Perspektif Ke Depan. Diversifikasi Pangan dan transformasi Pembangunan Pertanian. Editor: Ariani,M dkk. Badan Penelitian dan 
Pengembangan Pertanian, Kementerian Pertanian. Jakarta.

Halik, A. 2007. Ketahanan Pangan Masyarakat Pedesaan : "Studi Kasus di Desa Pammusureng, Kecamatan Bonto Cani, Kabupaten Bone". Jurnal Agrisistem 3 (2) : (ISSN 1858-4330)

Hariyadi, P. 2010. Penguatan Industri Penghasil Nilai Tambah Berbasis Potensi Lokal (Peranan Teknologi Pangan untuk Kemandirian Pangan). Jurnal Pangan, 19 (4) : 295-301

Kosim, S. M. 2008. Buku Ajar Neonatologi edisi 1. Badan Penerbit IDAI. Jakarta.

Pujoharso, C. 2013. “Aplikasi Teori Konsumsi Keynes Terhadap Pola Konsumsi Makanan Masyarakat Indonesia”. Jurnal Ekonomi Fakultas Ekonomi dan Bisnis Universitas Brawijaya.

Ramli, A. K. E., Inder, K. J., Bowe, S. J., Jacobs, J. and Dibley, M. J. 2009, "Prevalence and Risk Factors for Stunting and Severe Stunting Among Under-fives in North Maluku Province of Indonesia. BMC. Pediatrics, 9:64
Soblia, E.T. 2009. Tingkat Ketahanan Pangan Rumah tangga, Kondisi Lingkungan, Morbiditas, Dan Hubungannya Dengan Status Gizi Anak Balita Pada Rumah tangga Di Daerah Rawan Pangan Banjarnegara, Jawa Tengah, Departemen Gizi Masyarakat Fakultas Ekologi Manusia Institut Pertanian Bogor. Bogor.

Soekirman. 2000. Ilmu Gizi dan Aplikasinya untuk Keluarga dan Masyarakat, Direktorat Jendral Pendidikan Tinggi Departemen Pendidikan Nasional. Jakarta.

\section{Peraturan Perundangan}

Undang-Undang Republik Indonesia Nomor 7 Tahun 1996 tentang Pangan.

Peraturan Presiden Republik Indonesia Nomor 83 Tahun 2006 tentang Pembentukan Dewan Ketahanan Pangan. Keputusan Menteri Kesehatan Nomor 1995/Menkes/SK/XII/2010 tentang Standar Antropometri Penilaian Status Gizi Anak. 